\title{
PENTINGNYA KOMANDO OPERASI KHUSUS TNI DALAM PENCEGAHAN DAN PENANGGULANGAN TERORISME
}

\author{
Ari Setyo Nugroho ${ }^{1}$
}

\begin{abstract}
Abstrak: Terorisme adalah ancaman nyata dan aktif yang dihadapi oleh bangsa Indonesia, oleh karenanya diperlukan penanganan seriur,komprehensif, dan kontinue karena yang kita hadapi tidak hanya aksi terornya tetapi lebih jauh daritu yakni ideologi, ideologi yang dengan mudah menyebar jika pemerintah tidak bisa meracik serta memberi bumbu yang pas dalam sebuah pengambilan kebijakan, penanganan tersebut harus mencakup upayaupaya penindakan secara operasional, proteksi (perlindungan), pencegahan dan penangkalan, penanganan permasalahan hulu (akar masalah) dan upaya deradikalisasi. Sehingga, saaat ini sudah menjadi kebutuhan untuk membentuk Komando Operasi Khusus TNI (Indonesian Special Operation Command) guna tugas-tugas sangat khusus, terutama pencegahan dan penanggulangan terorisme serta penumpasan gerakan separatis di Indonesia
\end{abstract}

Kata Kunci: terorisme, separatis, komando operasi khusus.

\section{PENDAHULUAN}

\subsection{Latar Belakang}

Perubahan politik dunia yang terjadi di era globalisasi, telah menghadirkan suatu kompetisi antarbangsa. Kondisi tersebut cenderung mengarah pada perebutan pengaruh yang cukup ketat, baik global, regional maupun nasional. Perkembangan tersebut antara lain menyebabkan terjadinya perubahan pada situasi keamanan dunia dengan munculnya isu-isu keamanan baru.

Isu keamanan pada dekade terakhir ini makin kompleks dengan meningkatnya aktivitas terorisme. Bentuk kejahatan terorisme makin kompleks karena dikendalikan oleh aktor-aktor dengan jaringan lintas negara yang sangat rapi, serta adanya dukungan finansial.Disinilah Polri sebagai institusi yang didaulat untuk menumpas gerakan terorisme dituntut untuk bertindak secara professional.

\subsection{Permasalahan}

Masih melekat dalam benak ingatan kita saat Densus 88 melakukan penyergapan di dusun Beji, Kedu, Temanggung terhadap salah seorang dari pelaku hotel Marriot, Detasemen 88 Anti Teror berhasil menewaskan seorang pelaku teror dalam waktu yang bisa dikatakan cukup lama yakni 17 jam, setelah uji DNA diketahui sebagai Ibrahim alis boim orang yang pernah bekerja sebagai penata bunga di Florist Ritz Carlton yang menghilang pasca peledakan di Hotel JW Marriott dan Ritz-Carlton. Dari kejadian di Temanggung itu banyak kalangan yang menilai bahwa Polri dalam hal ini Detasemen 88 Anti Teror kurang cakap, sigap, dan efektif dalam penangkapan terorisme. Kurang keefektifannya tersebut terilhat jelas pada rentang waktu penyergapan hingga tertangkapnya pelaku yang memakan waktu terlalu lama. Pada sisi taktik dan strategi pun Detasemen 88 Anti Teror terlalu serampangan, terbukti hanya untuk menangkap satu tersangka terorisme yang hanya memiliki senjata dan bom yang terbatas, detasemen 88 Anti Teror harus mengeluarkan, menembakan ribuan amunisi untuk membombardir rumah tempat tersangka bersembunyi. Berbeda dengan Detasemen Antiteror milik TNI yang bisa menyergap pelaku terorisme dengan cepat seperti pembajakan Pesawar Garuda Woyla di Thailand beberapa tahun lalu, dan pembajakan Kapal Sinar Kudus di Somalia yang hanya memakan waktu beberapa jam saja.Maraknya aksi terorisme di Indonesia membuat kinerja Kepolisian dipertanyakan oleh masyarakat, tidak hanya itu kepolisian dengan Densus 88nya juga sering di anggap lambat dan kadang salah sasaran dalam penangkapan target operasi.

Perbedaan kemampuan antara TNI dan Polri memang bisa dimaklumi karena dalam pendidikannya sendiripun, Polri lebih menekankan pada pendidikan personal kemasyarakatan seperti penegakan hukum dan kriminalitas. Berbeda dengan TNI yang memang pendidikannya lebih menekankannya pada pembinaan fisik seperti latihan perang, jungle and sea survival, paramiliter, bahkan doktrin berani mati demi negara dan sebagainya, sehingga insting memburu mereka lebih tajam dan mumpuni. Walaupun Detasemen 88 Anti Teror juga menjalani khursus seperti itu, namun kemampuannya tetap tidak bisa disamakan oleh TNI, sebab setelah anggota Polri yang

Ari Setyo Nugroho merupakan pemerhati Pertahanan dan Kedaulatan Indonesia. Penulis dapat dihubungi melalui email di alamat: intifada_fianchetto@yahoo.com 
direkomendasikan masuk kesatuan khusus itu, mereka hanya menjalani khursus tersebut selama beberapa tahun, beda dengan TNI yang memang dari pendidikan hingga masa pensiunnya tetap tetap dididik dan dilatih untuk hal tersebut.

Berikut adalah beberapa kejadian terorisme yang telah terjadi di Indonesia dan instansi Indonesia di luar negeri:

\section{Tahun 2000}

Bom Kedubes Filipina, 1 Agustus 2000, 2 orang tewas dan 21 orang lainnya luka-luka, termasuk Duta Besar Filipina Leonides T Caday. Bom Kedubes Malaysia, 27 Agustus 2000. Granat meledak di kompleks Kedutaan Besar Malaysia di Kuningan, Jakarta. Tidak ada korban jiwa. Bom Bursa Efek Jakarta, 13 September 2000. Ledakan mengguncang lantai parkir P2 Gedung Bursa Efek Jakarta. 10 orang tewas, 90 orang lainnya luka-luka. Bom malam Natal, 24 Desember 2000. Serangkaian ledakan bom pada malam Natal di beberapa kota di Indonesia, merenggut nyawa 16 jiwa dan melukai 96 lainnya serta mengakibatkan 37 mobil rusak.

\section{Tahun 2001}

Bom Gereja Santa Anna dan HKBP, 22 Juli 2001. 5 orang tewas. Bom Plaza Atrium Senen Jakarta, 23 September 2001. Bom meledak di kawasan Plaza Atrium, Senen, Jakarta. 6 orang cedera. Bom restoran KFC, Makassar, 12 Oktober 2001. Ledakan bom mengakibatkan kaca, langit-langit, dan neon sign KFC pecah. Tidak ada korban jiwa. Sebuah bom lainnya yang dipasang di kantor MLC Life cabang Makassar tidak meledak. Bom sekolah Australia, Jakarta, 6 November 2001. Bom rakitan meledak di halaman Australian International School (AIS), Pejaten, Jakarta.

\section{Tahun 2002}

Bom Tahun Baru, 1 Januari 2002. Granat manggis meledak di depan rumah makan ayam Bulungan, Jakarta. Satu orang tewas dan seorang lainnya luka-luka. Di Palu, Sulawesi Tengah, terjadi empat ledakan bom di berbagai gereja. Tidak ada korban jiwa. Bom Bali, 12 Oktober 2002. Tiga ledakan mengguncang Bali. 202 korban yang mayoritas warga negara Australia tewas dan 300 orang lainnya luka-luka. Saat bersamaan, di Manado, Sulawesi Utara, bom rakitan juga meledak di kantor Konjen Filipina, tidak ada korban jiwa. Bom restoran McDonald's, Makassar, 5 Desember 2002. Bom rakitan yang dibungkus wadah pelat baja meledak di restoran McDonald's Makassar. 3 orang tewas dan 11 luka-luka.

\section{Tahun 2003}

Bom Kompleks Mabes Polri, Jakarta, 3 Februari 2003, Bom rakitan meledak di lobi Wisma Bhayangkari, Mabes Polri Jakarta. Tidak ada korban jiwa. Bom Bandara Soekarno-Hatta, Jakarta, 27 April 2003. Bom meledak dii area publik di terminal $2 \mathrm{~F}$, bandar udara internasional Soekarno-Hatta, Cengkareng, Jakarta. 2 orang luka berat dan 8 lainnya luka sedang dan ringan. Bom JW Marriott, 5 Agustus 2003. Bom menghancurkan sebagian Hotel JW Marriott. Sebanyak 11 orang meninggal, dan 152 orang lainnya mengalami luka-luka.

\section{Tahun 2004}

Bom Palopo, 10 Januari 2004. Menewaskan empat orang. Bom Kedubes Australia, 9 September 2004. Ledakan besar terjadi di depan Kedutaan Besar Australia. 5 orang tewas dan ratusan lainnya luka-luka. Ledakan juga mengakibatkan kerusakan beberapa gedung di sekitarnya seperti Menara Plaza 89, Menara Grasia, dan Gedung BNI. (Lihat pula: Bom Kedubes Indonesia, Paris 2004) Ledakan bom di Gereja Immanuel, Palu, Sulawesi Tengah pada 12 Desember 2004.

\section{Tahun 2005}

Dua Bom meledak di Ambon pada 21 Maret 2005. Bom Tentena, 28 Mei 2005. 22 orang tewas. Bom Pamulang, Tangerang, 8 Juni 2005. Bom meledak di halaman rumah Ahli Dewan Pemutus Kebijakan Majelis Mujahidin Indonesia Abu Jibril alias M lqbal di Pamulang Barat. Tidak ada korban jiwa. Bom Bali, 1 Oktober 2005. Bom kembali meledak di Bali. Sekurang-kurangnya 22 orang tewas dan 102 lainnya luka-luka akibat ledakan yang terjadi di RAJA's Bar dan Restaurant, Kuta Square, daerah Pantai Kuta dan di Nyoman Café Jimbaran Bom Pasar Palu, 31 Desember 2005. Bom meledak di sebuah pasar di Palu, Sulawesi Tengah yang menewaskan 8 orang dan melukai sedikitnya 45 orang.

\section{Tahun 2009}

Bom Jakarta, 17 Juli 2009. Dua ledakan dahsyat terjadi di Hotel JW Marriott dan RitzCarlton, Jakarta. Ledakan terjadi hampir bersamaan, sekitar pukul 7.00 WIB.

\section{Tahun 2011}

Bom bunuh diri di Gereja Bethel Injil Sepenuh, Kepunton-Surakarta pada Minggu 25 September 2011

\section{Tahun 2012}

18 Agustus 2012, Terjadi aksi pelemparan granat terhadap anggota polisi yang sedang berjaga di pos pengamanan Lebaran 06 Gladag 
Surakarta. Tidak ada korban jiwa maupun luka dalam peristiwa ini. 30 Agustus 2012, Terjadi penembakan terhadap pos polisi dekat swalayan Matahari Singosaren, Solo. Dalam peristiwa itu Aipda Widata luka-luka dan dirawat di RS PKU Muhamddiyah Solo. Sedangkan Bripka Dwi Data (53) tewas akibat ditembak lima kali di bagian badan dan tangan.15 November 2012, Kapolsek Poso Pesisir Utara, Sulawesi Tengah AKP Nicklas Karauwan diberondong tembakan oleh orang tidak dikenal. Dalam penyerangan pada pukul 12.00 itu Nicklas berhasil menyelamatkan diri. 22 Desember 2012, Setelah dirawat secara intensif di RS Undata Palu, Sulteng, Briptu Eko Wijaya Sumarno ahirnya meninggal dunia. Eko adalah anggota Brimob Polda Sulteng yang menjadi korban baku tembak dengan kelompok teror pada Kamis (20/12) siang. Baku tembak terjadi di Desa Tambarana, Poso Pesisir dan sekitar Gunung Kalora, Sulawesi Tengah. Tiga Brimob tewas dan tiga lainnya luka saat itu.

\section{Tahun 2013}

16 Agustus, Penembakan terhadap anggota Polri di Pondok Aren Tangerang. Serangkaian aksi peledakan bom maupun teror lainnya diduga didalangi oleh kelompok Jamaah Islamiyah ( J ) yang memiliki keterkaitan secara langsung dengan jaringan terorisme internasional, seperti Al-Qaeda. JI memiliki tujuan untuk membentuk Negara Islam yang meliputi Thailand, Malaysia, Singapura, Indonesia dan Filipina.Selain JI, terdapat beberapa kelompok lain yang juga dideskripsikan sebagai jaringan teroris yang perpanjangan tangannya melalui gerakan separatis yang ada di wilayah Filipina bagian selatan dan provinsi Aceh yang terletak di Indonesia. Menurut penjelasan dari Abuza (2003 dalam Hamilton-Hart, 2005), kelompokkelompok tersebut di antaranya adalah $A b u$ Sayaf Group (ASG) dan Moro Islamic Liberation Front (MILF) yang keduanya terletak di Filipina. Sementara untuk gerakan separatis yang ada di Aceh, Indonesia yang diduga juga merupakan perpanjangan tangan dari jaringan teroris adalah Gerakan Aceh Merdeka (GAM) sebagai kelompok "empati" yang merupakan salah satu kelompok yang diduga memiliki hubungan "marginal" dengan Al-Qaeda (Williams, 2003: 84 dalam Hamilton-Hart, 306).

Peneliti terorisme Sydney Jones memaparkan, Jl dibagi dalam 4 wilayah operasi di Asia Tenggara, yakni: Mantiqi 1: Malaysia, Singapura dan Thailand Selatan yang menitikberatkan pada pendanaan, Mantiqi 2: Indonesia (Jawa dan Sumatera). Dititikberatkan sebagai wilayah jihad, Mantiqi 3: Filipina, Brunei Darussalam, Malaysia Timur, Indonesia
(Kalimantan dan Sulawesi). Dititikberatkan sebagai daerah pelatihan, dan Mantiqi 4: Australia. Menitikberatkan pada aspek ekonomi dan pendanaan.

Berikut ini adalah beberapa kelompok

\begin{tabular}{|c|c|c|c|c|c|}
\hline Not & Kelompok & Negara & Tujuan & Keterangan & Status \\
\hline 15 & \begin{tabular}{|l|} 
Pattani United Liberation \\
Organization PULO
\end{tabular} & Thailand & \begin{tabular}{|l|} 
Pemisahan diri, \\
membentuk Negara \\
Islamm
\end{tabular} & $\begin{array}{l}\text { Motivasi keagarnaan, } \\
\text { diduga memiliki } \\
\text { hubungan dengan Abu } \\
\text { Sayyaf Group (ASG) }\end{array}$ & \\
\hline \begin{tabular}{|l|l}
2 & 6
\end{tabular} & $\begin{array}{l}\text { Guragan Mujahideen Islam } \\
\text { Pattani }\end{array}$ & Thalland & \begin{tabular}{|l|} 
Pemisahan diri, \\
membentuk Negara \\
Islamm
\end{tabular} & $\begin{array}{l}\text { Mottivasi keagamraan, } \\
\text { diduga memiliki } \\
\text { hubungan dengan AQ } \\
\text { and JI }\end{array}$ & \\
\hline \begin{tabular}{|c|c|}
3 & 3 \\
\end{tabular} & Wae Ka Raeh & Thailand & \begin{tabular}{|l|} 
Pemisahan diri, \\
membentuk Negara \\
Islam
\end{tabular} & $\begin{array}{l}\begin{array}{l}\text { Motivasi keagamaañ. } \\
\text { diduga memiliki } \\
\text { hubungan dengan AO } \\
\text { and لI }\end{array} \\
\end{array}$ & \\
\hline \begin{tabular}{|l|l|l}
4 & 1 \\
\end{tabular} & Hmang Guerilla & Laos & $\begin{array}{l}\text { Tuntutan olonomi! } \\
\text { pemisahan diri }\end{array}$ & Ethnonationalis & \\
\hline 55 & $\begin{array}{l}\begin{array}{l}\text { Cambodian Freedom Fighters } \\
\text { (CFF) }\end{array} \\
\end{array}$ & Cambodia & Politik lokal & & \\
\hline $6 \mid$ & Khmer Rouge & \begin{tabular}{|l|} 
Cambodia \\
\end{tabular} & Politik lokal & & \\
\hline 7 & Karen National Union & Myanmar & $\begin{array}{l}\text { Tuntutan olonomi! } \\
\text { pemisahan diri }\end{array}$ & Ethnonationalis & \\
\hline 8 & Kachin Delense Army & Myanmar & $\begin{array}{l}\begin{array}{l}\text { Tuntutan olonomit } \\
\text { pemisahan diri }\end{array} \\
\end{array}$ & Ethnonationalist & \\
\hline 9 & Eastern Shan State Army & Myanmar & $\begin{array}{l}\text { Tuntutan otonomi/ } \\
\text { pemisahan diri }\end{array}$ & Ethnonationalist & \\
\hline 10 & Ommat Liberation Front & Myanmar & $\begin{array}{l}\begin{array}{l}\text { Tuntutan olonomil } \\
\text { pemisahan diri }\end{array} \\
\end{array}$ & Ethnonationalis & \\
\hline 11 & $\begin{array}{l}\text { Kawthoolei Mus lim Liberation } \\
\text { Front }\end{array}$ & Myanmar & $\begin{array}{l}\begin{array}{l}\text { Tuntulan olonomil } \\
\text { pemisahan diri }\end{array} \\
\end{array}$ & Ethnonationalis & \\
\hline 12 & \begin{tabular}{|l|} 
Muslim Liberation \\
Organization of Burma
\end{tabular} & Myanmar & $\begin{array}{l}\begin{array}{l}\text { Tuntutan otonomil } \\
\text { pemisahan diri }\end{array} \\
\end{array}$ & Ethnonationalis & \\
\hline 13 & Jemaah Islamiyah & \begin{tabular}{|l|} 
Indonesia, \\
Malaysia, \\
Singapura, \\
Thaaland, \\
Filipina, \\
Kamboja \\
\end{tabular} & \begin{tabular}{|l|} 
Membentuk Negara \\
Islam di Asia \\
Tenggara
\end{tabular} & $\begin{array}{l}\text { Motivasi keagamaan, } \\
\text { terkait dengan } \mathrm{AO}\end{array}$ & \begin{tabular}{|l} 
Dimasukkan \\
dalam daftar \\
organisasi \\
teroris oleh AS \\
dan PBB
\end{tabular} \\
\hline \begin{tabular}{|l|l|}
14 &
\end{tabular} & Abu Sayyaf Group (ASG) & $\begin{array}{l}\text { Filipina } \\
\text { Selatan }\end{array}$ & $\begin{array}{l}\text { Pemisahan diri, } \\
\text { membentuk Negara } \\
\text { Islam }\end{array}$ & $\begin{array}{l}\text { Motivasi keagamaan, } \\
\text { terkait dengan AO }\end{array}$ & \begin{tabular}{|l} 
Dimasukkan \\
dalam daftar \\
organisasi \\
teroris oleh AS
\end{tabular} \\
\hline \begin{tabular}{|c|}
15 \\
\end{tabular} & \begin{tabular}{|l|} 
Moro Islamic Liberation Front \\
(MILF)
\end{tabular} & $\begin{array}{l}\text { South } \\
\text { Phillipines }\end{array}$ & \begin{tabular}{|l|} 
Tuntutan Otonomi, \\
pemisahan diri, dan \\
pembentukarn negara \\
Islam
\end{tabular} & $\begin{array}{l}\text { Motivasi keagamaan, } \\
\text { terkait dengan JI }\end{array}$ & \\
\hline 16 & $\begin{array}{l}\text { Moro National Liberation } \\
\text { Front (MNLF) }\end{array}$ & $\begin{array}{l}\text { Filipina } \\
\text { Selatan } \\
\end{array}$ & $\begin{array}{l}\text { Tuntutan Otonomi } \\
\text { pemisahan diri }\end{array}$ & Ethnonationalis & \\
\hline 17 & New People's Army & Filipina & Politik lokal & Komunis & \begin{tabular}{|l} 
Dimasukkan \\
dalam daftar \\
organisasi \\
teroris oleh AS
\end{tabular} \\
\hline
\end{tabular}

Tabel 1. Kelompok pemberontak dan teroris di Asia Tenggara

\subsection{Tujuan}

Mengaktikan kembali peran TNI dalam pemberantasan terorisme di Indonesia dan perlunya pembentukan komando operasi khusus TNI dalam pencegahan dan penanggulangan terorisme dan perlunya payung hukum yang mengatur antar aktor keamanan sehingga saling terintegrasi.

\subsection{Metode Penulisan}

Penulis mempergunakan metode observasi dan kepustakaan.Cara-cara yang digunakan pada penelitian ini adalah: Studi Pustaka Dalam metode ini penulis membaca buku-buku, artikel baik media cetak maupun elektronik yang berkaitan dengan penulisan makalah ini.

\section{PEMBAHASAN}

\subsection{Kerjasama Lintas TNI Polri}

Diperlukan pendekatan yang multi sektor dan multi aktor dalam penanganan masalah terorisme. Pemerintah bisa mengajak seluruh 
komponen masyarakat bersamasama membasmi teror untuk menghadirkan rasa aman bagi publik. Sudah saatnya TNI diberi mandat untuk ikut langsung dalam penanganan masalah terorisme melalui pemaksimalan kerja Komando Teritorial sebagaimana diminta oleh Presiden Susilo Bambang Yudhoyono. Disinilah kebutuhan akan payung hukum atau keputusan poilitik yang jelas, yang merinci tugas dan fungsi TNI agar tidak bertabrakan dengan fungsi penegakan hukum kepolisian. Penerjunan TNI dalam penanggulangan terorisme dijamin oleh UndangUndang. Dalam pasal 7 ayat 2 butir b (3) UU No 34 Tahun 2004 tentang TNI, disebutkan bahwa terorisme adalah bagian dari tugas TNI dalam Operasi Militer Selain Perang. Pelibatan TNI juga tidak lepas dari sistem pertahanan dan keamanan Indonesia yakni sistem Hankamrata yang menyebutkan bahwa komponen utama sistem tersebut adalah TNI/Polri

Menurut mantan Panglima TNI Jenderal Djoko Santoso Pengaktifan Detasemen Anti Teror TNI tidak akan tumpang tindih dengan Detasemen Khusus 88 Anti Teror Polri. Pihak TNI akan melakukan koordinasi dengan kepolisian. TNI akan menerapkan tiga pola anti teror, yaitu: Pertama: pendeteksian oleh satuan satuan intelijen dan satuan territorial. Kedua: satuan pencegahan yang bersifat persuasive dan edukatif dengan pembinaan teritorial dan Ketiga: adalah dengan pola penindakan.

\subsection{Komando Operasi Khusus TNI}

Wacana pembentukan Komando Operasi Khusus TNI (Indonesian Special Operation Command) akhir-akhir ini, yang didedikasikan untuk tugas-tugas sangat khusus, terutama pencegahan dan penanggulangan terorisme. Kehadiran Komando Operasi Khusus TNI menjadi keniscayaan, karena hakekat ancaman dan tingkat keperluan komando operasi TNI ini cukup meningkat. Kuantitas, kualitas, dan kompleksitas jaringan terorisme di dalam dan luar negeri semakin meningkat. Secara struktur keorganisasian, komando operasi baru TNI ini nanti akan langsung berada di bawah panglima TNI. Untuk saat-saat awal, kajian internal TNI menyatakan TNI AD melalui Komando Pasukan Khusus TNI AD menjadi pucuk pimpinan. Sebenarnya, selain Korps Baret Merah itu, ada beberapa lagi pasukan khusus di lingkungan TNI yang berkemampuan intelijen, kontra intelijen, pertempuran trimatra (beraksi di laut, udara, dan darat), dan lain-lain. Mereka adalah Detasemen Jalamangkara Korps Marinir TNI AL, Komando Pasukan Katak TNI AL, dan Detasemen B90 Bravo Korps Pasukan Khas TNI AU. Masih ada lagi --bukan setingkat komando operasi-Batalion Intai Amfibi Korps Marinir TNI AL, yang fungsinya lebih mirip dengan US Marine Scouts pada Korps Marinir Amerika Serikat. Kekuatan, kemampuan, dan doktrin dari seluruh pasukan khusus TNI itulah yang akan "dilebur" di dalam Komando Operasi Khusus TNI tanpa menghilangkan identitas dan doktrin awal pasukan. Menurut Komandan Jenderal Komando Pasukan Khusus TNI AD, Mayor Jenderal TNI Agus Sutomo Namun TNI akan mengaplikasi model Singapura. Organisasinya kecil namun unsurnya lengkap. Pada masa damai, unsurunsur itu kembali ke satuan induk; saat diperlukan langsung terintegrasi.

\subsection{Payung Hukum Pengaktifan TNI dalam pemberantasan Terorisme}

Penerbitkan regulasi sebagai elaborasi UU Nomor 34/2004 tentang Tentara Nasional Indonesia, dan UU 2/2002 tentang Kepolisian Negara Republik Indonesia, untuk mengatur ketentuan lebih rinci tentang "Rule of Engagement" (aturan pelibatan) TNI, terkait tugas Operasi Militer Selain Perang, termasuk aturan pelibatan TNI dalam mengatasi terorisme dan tugas perbantuan TNI terhadap Polri. Kedua UU tersebut bisa menjadi sebuah embrio untuk menetaskan SKB, PP ataupun UU yang mampu memayungi Terbentuknya Komando Operasi Khusus TNI (Indonesian Special Operation Command) serta mengejawantahkan Tugas, peran dan fungsi dari Komando Operasi Khusus TNI itu sendiri.

\subsection{Pembentukan Badan Nasional Penanggulangan Teroris Sebagai Langkah Mengaktifkan Kembali peran TNI}

Setelah diadakan evaluasi pengembangan dari Desk Anti Teror Menkpolhukam yang sudah tidak efektif lagi dalam melaksanakan tugasnya, diadakan pengkajian ulang lebih mendalam terhadap UU No. 15 Tahun 2003 tentang Pemberantasan Tindak Pidana Terorisme. Peninjauan meliputi kelembagaan dan instrumen hukum badan anti teror dengan mengeluarkan Undang-undang khusus. Karena tidak efektifnya kerja Desk Anti Teror Menkopolhukam selama ini, kalangan akademisi lalu mengusulkan pembentukan Badan Nasional Penanggulangan Terorisme untuk melayani seluruh kebutuhan aktivitas penanggulangan terorisme dari fase pencegahan, penindakan, perlindungan dan persiapan. Badan ini dapat dipimpin oleh seorang kepala yang bertanggungjawab langsung kepada Presiden. 
Dikeluarkannya rekomendasi oleh Komisi I DPR dan assessment terhadap dinamika terorisme, maka pada tanggal 16 Juli 2010 Presiden Republik Indonesia menerbitakan Peraturan Presiden Nomor 46 Tahun 2010 tentang Badan Nasional Penanggulangan Terorisme, dan mengangkat Irjen Pol (Purn) Drs. Ansyaad Mbai, M.M. sebagai Kepala Badan Penganggulangan Terorisme (Keputusan Presiden Nomor 121/M. Tahun 2010).

\section{PENUTUP}

\subsection{Kesimpulan}

Terorisme adalah ancaman nyata dan aktif yang dihadapi oleh bangsa Indonesia, oleh karenanya diperlukan penanganan seriur,komprehensif, dan kontinyu karena yang kita hadapi tidak hanya aksi terornya tetapi lebih jauh daritu yakni ideologi, ideologi yang dengan mudah menyebar jika pemerintah tidak bisa meracik serta memberi bumbu yang pas dalam sebuah pengambilan kebijakan, penanganan tersebut harus mencakup upaya-upaya penindakan secara operasional, proteksi (perlindungan), pencegahan dan penangkalan, penanganan permasalahan hulu (akar masalah) dan upaya deradikalisasi. Ketika pihak kepolisian dengan Densus 88nya dinilai kurang berhasil dalam mengatasi masalah terorisme, kini saatnya pemerintah member porsi lebih untuk TNI ikut dalam penanganan masalah terorisme. Dengan dibentuknya Komando Operasi Khusus TNI (Indonesian Special Operation Command) diyakini akan lebih mengurangi ruang gerak terorisme di Indonesia

\subsection{Saran}

Negara memang sudah mampu membangun kekuatan untuk mengungkap jaringan, menangkap pelaku, sehingga ratusan orang berhasil ditangkap dan diproses secara hukum. Namun akar masalah, khususnya masalah penyebaran ideologi dan perkembangan jaringan masih terus terjadi, diperlukan tindakan represif dalam membubarkan ideology mereka. Pemerintah sepatutnya bisa bertindak adil cara penanganan antara teroris dengan gerakan separatis seperti OPM yang sering hanya di labeli kelompok bersenjata padahal sama bahayanya. Pemerintah Indonesia harus melakukan evaluasi diri dalam isu terorisme agar tidak terjebak lebih dalam kepada kepentingan asing (Amerika cs.) dan menjadikan umat Islam yang mengusung ideologi Islam sebagai musuh. Jika ini terus dipelihara akan melahirkan kondisi kontraproduktif pada masa yang akan
datang.Indonesia yang dalam pemetaan J masuk wilayah Mantiqi 2(Jawa dan Sumatera) dititikberatkan sebagai wilayah jihad dalam artian sebagai medan pertempuran $\mathrm{JI}$ untuk wilayah Asia Tenggara, dan juga masuk wilayah Mantiqi 3: Filipina, Brunei Darussalam, Malaysia Timur, Indonesia (Kalimantan dan Sulawesi).

Dititikberatkan sebagai daerah pelatihan. Maka sudah menjadi kebutuhan pokok dan dan wajib hukumnya untuk membentuk Komando Operasi Khusus TNI (Indonesian Special Operation Command) guna tugas-tugas sangat khusus, terutama pencegahan dan penanggulangan terorisme serta penumpasan gerakan separatis di Indonesia.

\section{DAFTAR PUSTAKA}

BNPT. Profil Badan Nasional Penanggulangan Terorisme. [online] terdapat di: <http:///bnpt. go.id/index.php/profile> [diakses pada 3 September 2013].

Cipto, Bambang. 2007. Hubungan Internasional di Asia Tenggara: Teropong terhadap Dinamika, Realitas dan Masa Depan. Yogyakarta: Pustaka Pelajar.

Departemen Pertahanan Republik Indonesia. 2008. Buku Putih Pertahanan 2008. Jakarta: Departemen Pertahanan Republik Indonesia.

Firmansyah, Dian dkk. 2008. The Emergence of Terrorism in South East Asia. Defence and Security Management Studies ITB-Cranfield University.

Hamilton-Hart, Natasha. 2005. Terrorism in SoutheastAsia: Expert Analysis, Myopia, and Fantasy. Routledge: The Pacific Review, 18(3). p.303-325.

Indo Defense Blog. Indonesia Bentuk Komando Operasi Khusus TNI.[online] terdapat pada <http://indodefense.blogspot.com/2013/09/i ndonesia-bentuk-komando-operasikhusus.html> [diakses pada 3 September 2013].

Institute for Defense, Security and Peace Studies (IDSPS), Aliansi Jurnalis Independen (AJI) dan Frederich Ebert Stiftung (FES).2009.Pengaktifan Kembali Desk Anti Teror TNI. Newsletter. Media dan Reforasi Sektor Keamanan.6(8).

Ramelan, Prayitno. Pelibatan TNI Dalam Operasi Penindakan Terhadap Terorism [online] terdapat di:<http://ramalanintelijen.net/ $\gg p=2427>$ [diakses pada 2 September 2013] 